\title{
Antiamylase Potential of Telfairia occidentalis Leaves from Cameroon and Effect of Their Dietary Supplementation on Fasting Blood Glucose in Wistar Rats
}

\author{
Palla Nyamen Corine Leslie, Etoundi Omgba Cunégonde Blanche*, Gouado Inocent \\ Department of Biochemistry, Faculty of Science, University of Douala, Douala, Cameroon \\ Email: ${ }^{*}$ blancheetoundi@hotmail.fr
}

Received 7 September 2015; accepted 10 September 2015; published 17 September 2015

\begin{abstract}
The study of edible plants, especially in developing countries, might provide more affordable means for the management of diabetes. Telfairia occidentalis is one of the plants whose leaves are commonly consumed in Cameroon. This work hereby studied the antiamylasic potential of its aqueous leaves extract and the effect of its dietary supplementation on fasting blood glucose in Wistar rats. An aqueous extract (1:6) was prepared from shed-dried $T$. occidentalis leaves by maceration. Its antiamylase activity was evaluated in vitro and a phytochemical screening was realized. Its acute toxicity and its effect on an oral glucose tolerance test (OGTT) were evaluated in rats. The effect of $T$. occidentalis leaves dietary supplementation $(10 \%)$ on fasting blood glucose was studied for 28 days in rats fed with carbohydrate enriched diet, using Glibenclamide (0.3 $\mathrm{mg} / \mathrm{kg}$ body weight) as reference hypoglycemic drug. Results showed that there was total inhibition of $\alpha$-amylase activity in vitro by T. occidentalis aqueous leaves extract at $0.075 \mathrm{mg} / \mathrm{ml}$. The presence of tannins, flavonoids and anthocyanins was revealed by the phytochemical screening. No sign of toxicity was observed in rats after an oral administration of the extract at $2000 \mathrm{mg} / \mathrm{kg}$ body weight. The extract significantly hindered a rise in blood glucose at $400 \mathrm{mg} / \mathrm{kg}$ body weight during an oral glucose tolerance test. Dietary supplementation with $T$. occidentalis leaves caused a significant decrease $(p<0.05)$ in fasting blood glucose as compared to the positive control. Telfairia occidentalis leaves and their aqueous extract could be used in the management of hyperglycemia and diabetes.
\end{abstract}

Keywords

Telfairia occidentalis, Hyperglycemia, Antiamylase Potential

\section{Introduction}

Diabetes mellitus is a chronic disease which arises when there is a failure in pancreatic insulin secretion or when "Corresponding author.

How to cite this paper: Leslie, P.N.C., Blanche, E.O.C. and Inocent, G. (2015) Antiamylase Potential of Telfairia occidentalis Leaves from Cameroon and Effect of Their Dietary Supplementation on Fasting Blood Glucose in Wistar Rats. Journal of Biosciences and Medicines, 3, 61-66. http://dx.doi.org/10.4236/jbm.2015.39010 
the body can no more use insulin properly. Hyperglycemia is a frequent effect of poorly managed diabetes which can cause serious damage to the body with time, particularly to nerves and blood vessels [1]. Diabetes affects vital organs in the body and reduces life expectancy [2]. Worldwide, 382 million people were diabetic of who $46 \%$ were not diagnosed [3] and more than $80 \%$ of deaths caused by diabetes occur in less developed countries [4]. Actual treatments of diabetes mainly aim at reducing hyperglycemia and generally include a modification in lifestyle (dietetics and physical activity) and antidiabetic synthetic drugs [5]. Due to the side effects and the cost of synthetic drugs, research is being made on natural products in the course of finding new alternatives for diabetes management. The study of edible plants might therefore constitute a more affordable mean for prevention or treatment. Telfairia occidentalis Hook F (family Curcubitaceae) is an herbaceous creeping plant cultivated for its edible seeds and leaves [6]. Depending on the age, ecologic conditions and cultural practices, its leaves composition can vary [7]. In Cameroon, it is locally know as "okoribon" and is found in the preparation of various dishes. This work was designed to study the antiamylasic potential of Telfairia occidentalis aqueous leaves extract and the effect of their dietary supplementation on fasting blood glucose in Wistar rats.

\section{Materials and Methods}

\subsection{Collection of Plant Material and Extract Preparation}

Telfairia occidentalis was collected from local markets in Douala and was taken to the National Herbarium in Yaounde for identification. The leaves were shed-dried for 1 week, ground and stored at room temperature.

About $250 \mathrm{~g}$ of powdered leaves were soaked in $1500 \mathrm{ml}$ of distilled water in a covered plastic container, allowed to macerate for 48 hours in the dark at room temperature and filtered with a filter paper. The filtrate was dried in an oven at $45^{\circ} \mathrm{C}$ for 4 days to obtain concentrated extract which was dissolved accordingly in distilled water for various experimentations.

\subsection{In Vitro $\alpha$-Amylase Inhibition Assay}

The $\alpha$-amylase inhibitory activity was determined in vitro [8]. A mixture of $20 \mu \mathrm{l}$ of enzyme ( $30 \mu \mathrm{g} / \mathrm{ml}), 1380 \mu \mathrm{l}$ of tris-HCl buffer $\mathrm{pH} 6.9$ and $100 \mu \mathrm{l}$ of aqueous extract aliquot was pre incubated at $30^{\circ} \mathrm{C}$ for 20 minutes. Thereafter, the reaction was initiated by adding $100 \mu \mathrm{l}$ of starch solution (1\%). After incubating for 20 minutes, the reaction was stopped by adding $2 \mathrm{ml}$ of acidified iodine and the absorbance was read at $580 \mathrm{~nm}$. Various extract concentrations were used. The $\alpha$-amylase inhibitory activity was expressed as percentage inhibition.

\subsection{Phytochemical Screening}

A phytochemical screening was realized on $T$. occidentalis aqueous leaves extract to determine the presence of tannins [9], flavonoids [10] and anthocyanines [11].

\subsection{Experimental Animals}

Male and female Wistar rats aged of 3 months at least were bought from the Laboratory of Animal Biology of Douala University. They were kept in metabolic cages under a 12 hours dark/light cycle at room temperature for 2 weeks before any experimentation. They received standard laboratory chow and water ad libitum.

\subsection{Acute Toxicity Assay}

The acute toxicity of $T$. occidentalis aqueous leaves extract was evaluated according to the Organization for Economic Cooperation and Development, guideline 425 [12] with the limit test dose at $2000 \mathrm{mg} / \mathrm{kg}$ body weight. Female rats were divided into 2 groups of 5 each: a test group that received a single oral administration of $T$. occidentalis aqueous leaves extract at $2000 \mathrm{mg} / \mathrm{kg}$ body weight, and a control group that received distilled water. Signs of toxicity were monitored during 14 days after which subjects were humanely sacrificed and their blood collected. The commercial kit IMNESCO was used for determination of AST (Aspartate transaminase), ALT (Alanine transaminase), and total plasmatic protein [13] were determined.

\subsection{Effect of T, occidentalis Aqueous Leaves Extract on Oral Glucose Tolerance Test}

It was evaluated during an OGTT. Male rats were divided into 3 groups of 4 each. After 12 hours of overnight 
fasting, their glycemia was measured using SD CodeFree glucometer. Each group received two oral administrations: the positive control received $1 \mathrm{ml}$ of distilled water followed by $1 \mathrm{ml}$ of glucose solution $(2 \mathrm{~g} / \mathrm{kg})$, the test group received $1 \mathrm{ml}$ of $T$. occidentalis aqueous leaves extract $(400 \mathrm{mg} / \mathrm{kg})$ followed by $1 \mathrm{ml}$ of glucose solution $(2 \mathrm{~g} / \mathrm{kg})$ and the negative control received $1 \mathrm{ml}$ of distilled water twice. Glycemia was then measured for all groups at 30 minutes intervals during 2 hours.

\subsection{Effect of T. occidentalis Leaves Dietary Supplementation on Fasting Blood Glucose}

Four groups of 4 male rats each (positive control, test group, reference group and negative control) were used. After 12 hours of overnight fasting, their glycemia was measured. During 28 days, all groups except the negative control, received $65 \%$ sucrose enriched food, $10 \%$ glucose in drinking water and oral administration of fructose $(1 \mathrm{~g} / \mathrm{kg})$. For test group, the food was supplemented with $10 \%$ of $T$. occidentalis powdered leaves, and Glibenclamide $(0.3 \mathrm{mg} / \mathrm{kg})$ was administered orally to the reference group. For all animals, fasting glycemia was measured on days 9,18 and 28.

\subsection{Statistical Analyses}

STATGRAPHICS CENTURION XV.II and SPPS 17 were used for statistical analyses. Variables are presented as mean \pm standard deviation. Data were analyzed by the one way Analyses of variance test (ANOVA) followed by the least significant difference (LSD) post Hoc test. Values of $\mathrm{p}<0.05$ were considered significant.

\section{Results}

\subsection{In Vitro $\alpha$-Amylase Inhibitory Effect of T, occidentalis Aqueous Leaves Extract}

T. occidentalis aqueous leaves extract significantly $(\mathrm{p}<0.05)$ inhibited $\alpha$-amylase activity at low concentration. The enzyme's activity was totally inhibited by the extract at $0.075 \mathrm{mg} / \mathrm{ml}$ as shown in Figure 1.

\subsection{Phytochemical Screening}

The presence of flavonoids, tannins, and anthocyanins were revealed from the qualitative analyses realized on the aqueous leaves extract. Flavonoids were revealed by the appearance of a yellow colour, tannins by a bluish green precipitate and anthocyanins by an orange-red colour.

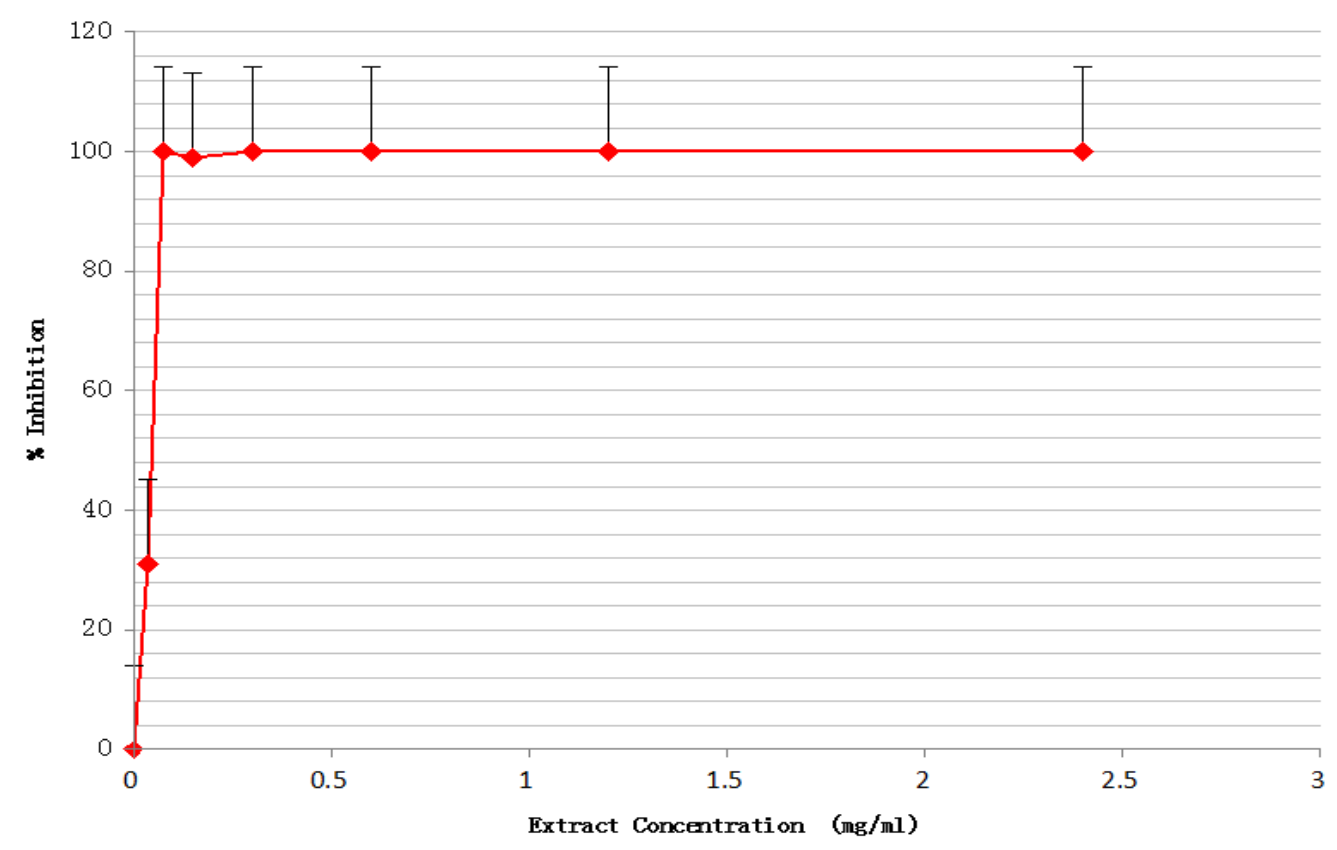

Figure 1. In vitro $\alpha$-amylase activity at various concentrations of $T$. occidentalis aqueous leaves extract. 


\subsection{Acute Toxicity Assay}

No death and no particular signs of toxicity were recorded after 14 days observation. The values obtained for AST, ALT and total plasmatic proteins for test group were not different $(\mathrm{p}>0.05)$ from control group (Table 1).

\subsection{Effect of T. occidentalis Aqueous Leaves Extract on Oral Glucose Tolerance Test}

The extract significantly inhibited a rise in blood glucose during the oral glucose tolerance test as shown in Figure 2. Thirty minutes after the beginning of the experiment, glycemia was significantly high in positive control and test groups as compared to the negative control. At 60 minutes, it was greater $(p<0.05)$ for positive control compared to test group. Furthermore, in test group, glycemia at 90 minutes and 120 minutes are significantly low compared to 30 minutes.

\subsection{Effect of T. occidentalis Leaves Dietary Supplementation on Fasting Blood Glucose}

Rats receiving only the carbohydrate enriched diet (sucrose, glucose and fructose) showed a significant increase in fasting glycemia from the $1^{\text {st }}$ to the last day. Their mean glycemia was $102.83 \pm 12.4 \mathrm{mg} / \mathrm{dl}$, thus corresponding to an impaired fasting blood glucose [14]. Dietary supplementation with $10 \% \mathrm{~T}$. occidentalis leaves significantly reduced fasting blood glucose from the $9^{\text {th }}$ to the last day of experiment (Table 2).

\section{Discussion}

Plants with antidiabetic potential exhibit various action mechanisms like enzyme inhibition [15]. Alpha amylase is one of the key enzymes involved in breaking down starch into absorbable glucose molecules [16]. Inhibiting this enzyme helps in reducing post prandial glycemia by reducing the speed of glucose absorption [17]. T. occidentalis aqueous leaves extract showed an anti $\alpha$-amylase activity at low concentration. This suggests the presence of compounds capable of inhibiting the enzyme. However, further investigation may help to find more precise mechanisms for this enzyme inhibiting activity.

Pharmacological properties of plants are generally attributed to their phytochemical compounds. A number of these like tannins, flavonoids and anthocyanins are reported to be antidiabetic [18]. Their presence was revealed in the extract as reported in a previous study [19]. They might be involved in the antiamylase activity of the aqueous extract, especially tannins which were reported to have antienzyme activity [20].

Transaminases (ALT, AST) and plasmatic proteins are some biochemical markers to evaluate hepatic, cardiac and muscular functions. These vital functions might be affected by a toxic effect and should therefore be verified during a toxicity assay [21]. In this work, there was no significant difference in the values obtained suggesting that

Table 1. Biochemical parameters after acute toxicity test.

\begin{tabular}{cccc}
\hline \multirow{2}{*}{ Groups } & \multicolumn{3}{c}{ Biochemical parameters } \\
\cline { 2 - 4 } & Total plasmatic protein $(\mathrm{mg} / \mathrm{ml})$ & ALT(U/l) & AST(U/l) \\
\hline Control & $1.20 \pm 0.2^{\mathrm{a}}$ & $2.6 \pm 0.5^{\mathrm{a}}$ & $1.2 \pm 0.2^{\mathrm{a}}$ \\
Test & $1.30 \pm 0.2^{\mathrm{a}}$ & $3.2 \pm 0.8^{\mathrm{a}}$ & $1.48 \pm 0.1^{\mathrm{a}}$ \\
\hline
\end{tabular}

Values are expressed as mean $\pm \mathrm{SD}, \mathrm{n}=5$. The data were analyzed by the ANOVA (test $\mathrm{p}<0.05$ ). Values affected by different letters in the same column are significantly different.

Table 2. Evolution of fasting blood glucose during dietary supplementation period.

\begin{tabular}{ccccc}
\hline \multirow{2}{*}{ Groups } & \multicolumn{4}{c}{ Fasting blood glucose (mg/dl) } \\
\cline { 2 - 5 } & Day 1 & Day 9 & Day 18 & Day 28 \\
\hline Positive control & $88.58 \pm 4.40^{\mathrm{a}}$ & $92.50 \pm 5.61^{\mathrm{a}}$ & $95.42 \pm 9.97^{\mathrm{a}}$ & $102.83 \pm 12.94^{\mathrm{a}}$ \\
Test & $88.58 \pm 4.25^{\mathrm{a}}$ & $93.25 \pm 10.24^{\mathrm{a}}$ & $80.92 \pm 10.74^{\mathrm{b}}$ & $77.34 \pm 5.59^{\mathrm{a}, \mathrm{b}}$ \\
Reference & $95.00 \pm 17.12^{\mathrm{a}}$ & $89.00 \pm 5.29^{\mathrm{a}}$ & $75.75 \pm 6.19^{\mathrm{b}}$ & $87.92 \pm 18.52^{\mathrm{a}, \mathrm{b}}$ \\
Negative control & $91.25 \pm 9.18^{\mathrm{a}}$ & $90.08 \pm 8.44^{\mathrm{a}}$ & $80.67 \pm 2.36^{\mathrm{b}}$ & $87.00 \pm 14.53^{\mathrm{a}, \mathrm{b}}$ \\
\hline
\end{tabular}

Values are expressed as mean $\pm \mathrm{SD}, \mathrm{n}=4$. The data were analyzed by the ANOVA (test $\mathrm{p}<0.05$ ). Values affected by different letters in the same column are significantly different. 


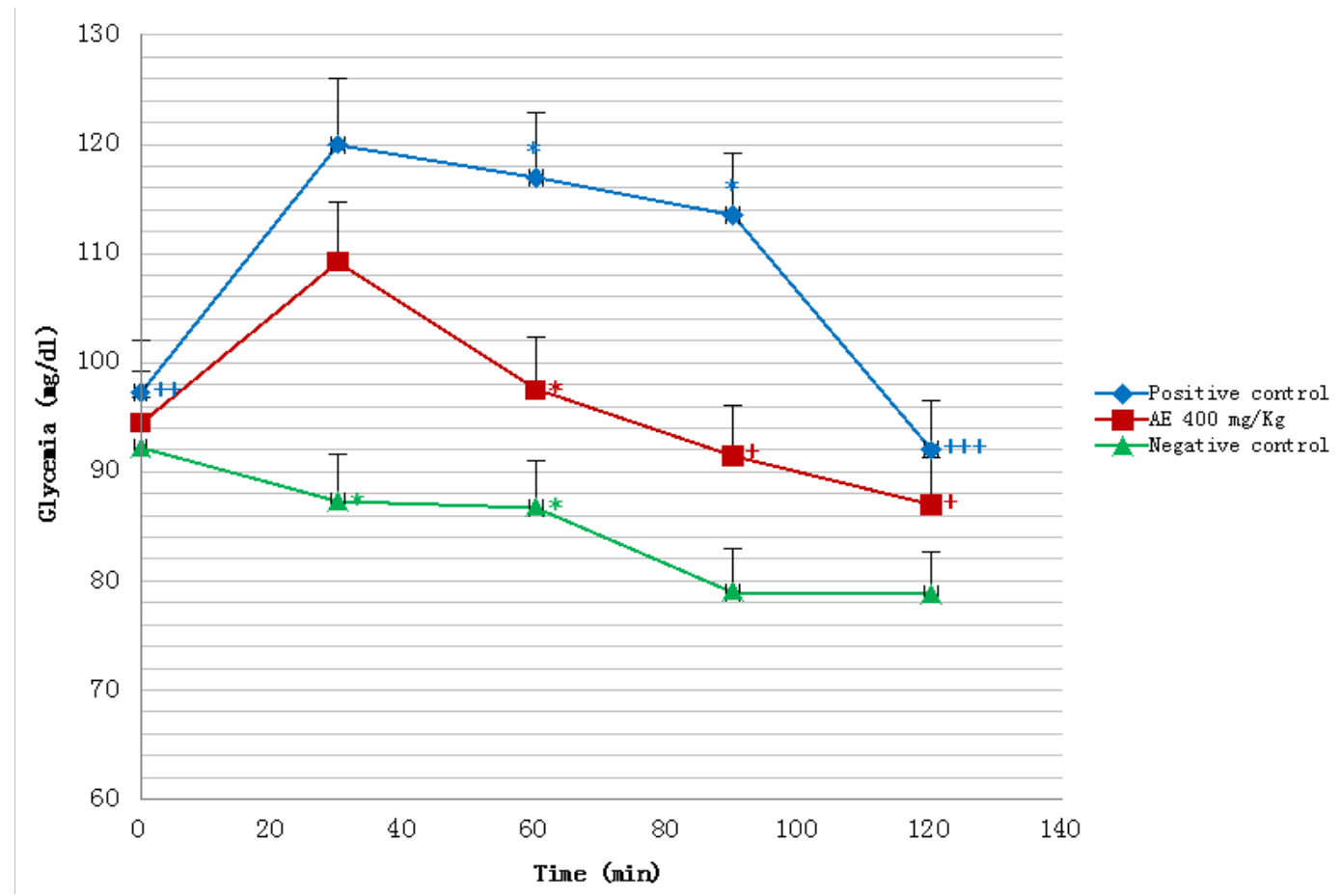

Figure 2. Effect $400 \mathrm{mg} / \mathrm{kg}$ of $T$. occidentalis aqueous leaves extract on glycemia during an OGTT (AE: aqueous extract; ${ }^{*}$ significant difference compared to two other groups; ${ }^{+}$significant compared to 30 minutes; ${ }^{++}$significant compared to 30 and 60 minutes; ${ }^{++}$significant compared to 30, 60 and 90 minutes).

T. occidentalis aqueous leaves extract was non toxic at $2000 \mathrm{mg} / \mathrm{kg}$ of body weight. This result is similar to the one obtained by other authors [22] who found that aqueous extract of $T$. occidentalis leaves was not toxic even at high doses. Furthermore, the extract significantly hindered a rise in blood glucose level during an OGTT as shown in Figure 2. This result suggests an antihyperglycemic activity as well as a capacity to improve glucose tolerance.

Dietary supplementation with $T$. occidentalis leaves significantly reduced fasting blood glucose in test group as compared to the positive control (Table 2). Moreover, it significantly prevented the carbohydrate enriched diet from causing a rise in fasting blood glucose throughout the experimental period. These reflect the antihyperglycemic activity of $T$. occidentalis leaves. The presence of antidiabetic phytochemicals could account for this result. It could also be substantiated by the capacity of the extract to inhibit $\alpha$-amylase activity and to slower blood glucose absorption, thereby improving glucose tolerance and post prandial glycemia. It is contrary to findings obtained by other researchers [6] who reported that $T$. occidentalis leaves significantly increased blood glucose level in rats. It might be attributed to difference in plant material preparation and treatment of animals.

\section{Conclusion}

The results obtained from the in vitro and in vivo experimentations reveal that $T$. occidentalis leaves from Cameroon possess antihyperglycemic properties. They might be attributed to the presence of antidiabetic photochemical but further investigations are needed to find out the bioactive molecules and mechanisms involved. These leaves and their aqueous extract could thus be used in the management of hyperglycemia and diabetes.

\section{References}

[1] World Health Organization (2015) Diabetes. Facts Sheet No. 312. http://www.who.int/mediacentre/factsheets/fs312/en/

[2] Baillot, A., Pelletier, C., Dunbar, P., Geiss, L., Johnson, J.A., Leiter, L.A. and Langlois, M.F. (2013) Profile of Adults with Type 2 Diabetes and Uptake of Clinical Care Best Practice: Results from the 2011 Survey on Living with Chronic Disease in Canada_Diabetes Component. Diabetes Research and Clinical Practice, 103, 11-19. http://dx.doi.org/10.1016/j.diabres.2013.11.022 
[3] International Diabetes Federation (2013) IDF Atlas of Diabetes. 6th Edition, International Diabetes Federation, Brussels.

[4] WHO (2014) Global Health Estimates: Deaths by Cause, Age, Sex and Country, 2000-2012. Geneva.

[5] Hemant, P., Sameer, S., Khajja, B.S., Kusum, J. and Jain, G.C. (2009) Evaluation of Hypoglycemic and Anti-Hyperglycemic Potential of Tridax procumbens (Linn.). BMC Complementary and Alternative Medicine, 9, 48. http://dx.doi.org/10.1186/1472-6882-9-48

[6] Adisa, W.A., Otamere, H.O., Osifo, C.U., Ediangbe, A.P., Ogarah, P.A. and Aigbogun, T.O. (2012) Plasma Glucose in Telfairia occidentalis Treated Rats. Advances in Applied Science Research, 3, 1551-1553.

[7] Olaniyi, J.O. and Odedere, M.P. (2009) The Effect of Mineral N and Compost Fertilizers on the Growth, Yield and Nutritional Values of Fluted Pumpkin (Telfairia occidentalis) in South Western Nigeria. Journal of Animal \& Plant Sciences, 5, 443-449.

[8] Komaki, E., Yamaguchi, S., Maru, I., Kinoshita, M., Kakeyi, K., Ohta, Y. and Tsukada, Y. (2003) Identification of Anti- $\alpha$-Amylase Components from Olive Leaf Extracts. Food Science Technology Research, 9, 35-39. http://dx.doi.org/10.3136/fstr.9.35

[9] Trease, G.E. and Evan, W.E. (1989) Trease and Evans Pharmacognosy. A Physician Guide to Herbal Medicine. 15th Edition, Baillere Tindall Ltd., London.

[10] Trease, G.E. and Evan, W.E. (1989) A Text Book of Pharmacognosy. 13th Edition, Baillere Tindall Ltd., London.

[11] Harbone, J.B. (1967) Comparative Biochemistry of the Flavonoids. Academic Press, London, New York.

[12] Organization for Economic Cooperation and Development (2008) Test No. 425: Acute Oral Toxicity: Up-and-Down Procedure, OECD Guidelines for the Testing of Chemicals, Section 4. OECD Publishing, Paris.

[13] Bradford, M.M. (1976) A Rapid and Sensitive Method for the Quantification of Microgram Quantities of Protein Utilizing the Principle of Protein-Dye Binding. Analytical Biochemistry, 72, 248-254.

[14] American Diabetes Association (2010) Standards of Medical Care in Diabetes. Diabetes Care, 33, S11-S61. http://dx.doi.org/10.2337/dc10-S011

[15] Wadkar, K.A., Magdum, C.S., Patil, S.S. and Naikwade N.S. (2008) Anti-Diabetic Potential and Indian Medicinal Plants. Journal of Herbal Medicine and Toxicology, 2, 45-50.

[16] AFifi, A.F., Kamel, E.M., Khalil, A.A., Foaad, M.A., Fawziand, E.M. and Houseny, M. (2008) Purification and Characterization of Alpha-Amylase from Penicillium olsonii under the Effect of Some Antioxydant Vitamins. Global Journal of Biotechnology and Biochemistry, 3, 14-21.

[17] Sangeetha, R. and Vedasree, N. (2012) In Vitro $\alpha$-Amylase Inhibitory Activity of the Leaves of Thespesia populnea. 2012, 1-4.

[18] Coman, C., Rugina, O.D. and Socaciu, C. (2012) Plants and Natural Compounds with Antidiabetic Action. Notulae Botanicae Horti Agobotanici, 40, 314-325. http://www.notulaebotanicae.ro

[19] Madukwe, E.U., Nwabunze, A.M. and Onyibalu, C.L. (2013) Bioavailability of Selected Phytochemicals in the Extract of Flutted Pumpkin (Telfairia occidentalis), Tomato (Lycopersium esculentum) and Eggplant (Solanum elongena). International Journal of Basic and Applied Sciences, 2, 251-257. http://www.sciencepubco.com/index.php/IJBAS

[20] Hurtel, J.-M. (2003) Plantes médicinales et diabète. http://www.phytomania.com

[21] World Health Organization (2000) General Guidelines for Methodologies on Research and Evaluation of Traditional Medicine. WHO/EDM/TRM/2000.1.

[22] Ekpeyon, C.E., Akpan, E.E. and Udoh N.S (2012) Phytochemistry and Toxicity Studies of Telfairia occidentalis Aqueous Leaves Extract in Liver Biochemical Indices in Wistar Rats. American Journal of Medicine and Medical Sciences, 2, 103-110. http://dx.doi.org/10.5923/j.ajmms.20120205.03 